\title{
At søge ly i Pandoras æske, \\ eller frygt, sikkerhed og storbyen
}

Oversat fra engelsk af Michael Hviid J acobsen

Frygten er over os, og det er i særlig grad i de moderne storbyer, at denne frygt materialiserer og formerer sig. Frygten næres og fremskyndes af globaliseringen, der skaber et allestedsnærværende grænseland, der er præget af usikkerhed og utryghed. Globaliseringens konsekvenser er nu rykket ind $\mathrm{i}$ hjertet af storbyerne, der afspejler samfundets iboende ambivalens; de er på en og samme tid hjemstedet for forskellighed, fællesskab og fortryllelse, men også arnestedet for intimidering, segregering og mistænkelighed - og det er særligt sidstnævnte tendenser, der i dag er fremherskende. Storbyen er i stigende grad blevet affortryllet, og livet i storbyen associeres med frygt og fortvivlede forsøg på at forskanse sig. At søge ly i Pandoras æke er som at sparke døren ind til helvedes forgård, hvorfra alle ulykker og farer blot venter på at undslippe. 
$\mathrm{I}$

fraværet af muligheden for eksistentiel tryghed er vi nu nødt til at tage til takke med sikkerhed eller forestillingen om sikkerhed", skriver redaktørerne af The Hedgehog Review i deres introduktion til et særnummer dedikeret til frygt ${ }^{1}$.

Grunden, hvorpå vores livsudsigter forventes at hvile, er indrømmet skrøbelig - på samme måde som vores jobs og de virksomheder, der udbyder dem, vores partnere og netværk af venner, vores anseelse i det bredere samfund og den selvværd og selvsikkerhed, der følger med alt dette. "Fremskridtet", der engang udgjorde den mest ekstreme manifestation af radikal optimisme og et løfte om en universel fælles og vedvarende lykke, har bevæget sig over i den diametralt modsatte pol bestående af dystopiske og fatalistiske forudanelser. Fremskridtet står nu som truslen om en ubarmhjertig og uundgåelig forandring, der indvarsler fraværet af fred og ro men derimod tilstedeværelsen af konstant krise og spænding, der hindrer selv et øjebliks hvile; en slags "Jerusalem brænder"-stoleleg, hvor et øjebliks uopmærksomhed resulterer i et uomstødeligt nederlag og i en ekskludering, som ikke kan appelleres. I stedet for store forventninger og smukke drømme fremmaner "fremskridtet" nu snarere en mareridtsagtig søvnløshed af at "føle sig forladt", at falde af vognen eller ud af vinduet på et hastigt accelererende køretøj.

Ude af stand til at bremse forandringens ufattelige fart, for slet ikke at tale om muligheden for at forudsige eller kontrollere dens retning, fokuserer vi i stedet på de ting, vi kan, eller som vi føler eller er overbevidste om vi kan, påvirke: Vi forsøger at beregne og minimere de risici, som vi selv eller de, der for øjeblikket står os nær, kan blive ofre for samt de uendelige og udefinerbare farer, som en uigennemskuelig verden og dens usikre fremtid har i baghånden til os. Vi er fordybede i at opdage "de syv tegn på kræft" eller "de fem symptomer på depression" eller i at uddrive det forhøjede blodtryks, det stigende kolesteroltals, stressets og fedmens onde ånder. Vi forsøger med andre ord at finde erstatningsskydeskiver, efter hvilke vi kan affyre den overskydende frygt, som har fået spærret sine naturlige afløb, og vi finder sådanne provisoriske skydeskiver ved at tage detaljerede forholdsregler mod at udsætte os for cigaretrygning, fedme, fast food, usikker sex eller solstråler. De af os, der har råd, befæster vores liv mod alle synlige og usynlige, nuværende eller forventede, kendte eller indtil videre ukendte, diffuse men allestedsnærværende farer ved at låse os inde bag hjemmets fire vægge, proppe indgangene til vores boliger med tv-kameraer, hyre bevæbnede vagter, køre i pansrede biler (som de berygtede SUV'ere - Sport Utility Vehicles), bære særlig armeret påklædning (som de såkald te big soled shoes) eller ved at tage timer i selvforsvar. "Problemet er", siger David L. Altheide, "at disse aktiviteter bekræfter og hjælper med til at skabe en følelse af uorden, som vores handlinger dermed er med til at fremskynde “2 . Hver ekstra lås, der sættes på hoveddøren som reaktion på de gentagne rygter om udenlandsk-udseende kriminelle på rov, og hver ændring i diæten som respons på de skiftende udbrud af "fødevarepanik", får verden til at 


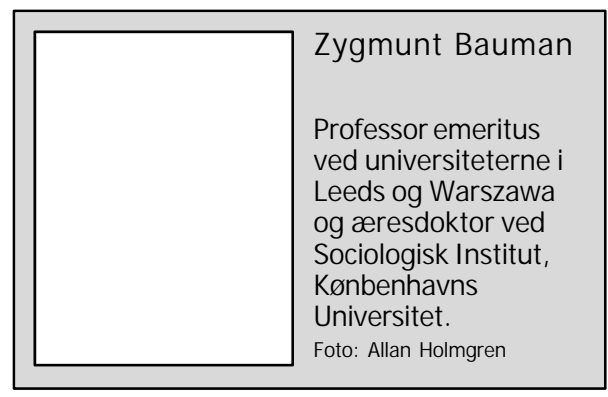

tage sig mere lumsk og frygtindgydende ud og tilskynder flere forsvarshandlinger - der sikkert selv desværre vil medføre noget tilsvarende. Vores frygt bliver selvforlængende og selvforstærkende. Den har samtidig opnået sit eget momentum.

En mængde kommerciel kapital kan akkumuleres fra disse følelser af usikkerhed og frygt - og bliver det. "Annoncører", kommenterer Stephen Graham, "har bevidst udnyttet den udbredte frygt for katastrofisk terrorisme til yderligere at fremme salget af særdeles profitable SUV'ere". De benzinslugende uhyrer - der med grov fejlagtigt er blevet betegnet Sport Utility Vehicles, og som allerede står for $45 \%$ af hele bilsalget i USA - har meldt sig til tjeneste i storbyens hverdagsliv som "forsvarskapsler". SUV'ere

signalerer sikkerhed, der - på samme måde som de befæstede fællesskaber, hvori de ofte kører - portrætteres i reklamer, som om de var immune overfor det risikable og uforudsigelige byliv udenfor ... Sådanne køretøjer forekommer at berolige den frygt, som den urbane middelklasse føler, når den bevæger sig - eller holder i kø - i sit "hjemlands" by. ${ }^{3}$

På samme måde som den flydende kapital, der er klar til en hvilken som helst investeringsmulighed, kan frygtkapitalen anvendes til enhver form for profit - kommerciel såvel som politisk. Personlig sikkerhed er blevet et vigtigt, måske endda det vigtigste, salgsargument inden for alle typer af markedsføringsstrategier. "Lov og orden", der i stadig stigende grad reduceres til løftet om personlig sikkerhed, er blevet et centralt, måske enddadet mest centrale, salgsargument i politiske manifester og i valgkampagner. Fremvisningen af truslerne mod den personlige sikkerhed er blevet et fremtrædende, måske endda det mest fremtrædende, aktiv i massemediernes kamp om lyttere og seere (der således føjer endnu mere succes til både markedsføringsindustriens og den politiske arenas anvendelse af frygtkapital). Som Ray Surette udtrykte det, består verden, som den afspejles på tv, af "borgerfår", der skal beskyttes fra "kriminelle ulve" af "politiets hyrdehunde" 
Alt dette kan ikke undgå at påvirke, endda revolutionere, vilkårene for livet $\mathrm{i}$ storbyen, vores oplevelse af bylivet og de forhåbninger og bange anelser, som vi er tilbøjelige til at associere med de urbane omgivelser. Og når vi beskæftiger os med vilkårene for byliv, så beskæftiger vi os faktisk med omstændighederne for hele menneskeheden. Ifølge aktuelle fremskrivninger vil to ud af tre mennesker om cirka to årtier leve i byerne, og for os hidtil ukendte bynavne som Chongking, Shenyan, Pune, Ahmadabad, Surat eller Yangon vil hver især repræsentere mere end fem millioner mennesker presset sammen i nye sammensmeltede storbyer - på samme måde som med andre bynavne, såsom Kinshasa, Abijan eller Belo Horizonte, der for nuværende mere associeres med eksotiske feriesteder end med frontlinien for samtidens moderniseringskampe. Nytilkommerne til den urbane sammenhobnings superliga, der alle allerede enten er eller befinder sig på randen af fallit, bliver nødt til i det mindste "på tyve år at forsøge at håndtere den samme type af problemer som London eller New York kun med besvær i løbet af halvandet århundrede kunne tage fat på“ ${ }^{\circ}$. Alt hvad vi for nuværende ved om de berygtede problemer og følelser af frygt, der plagede de gamle storbyer, vil blive overskygget af de forhindringer, som de nye giganter er nødsagede til at konfrontere.

Vores klode har endnu lang vej, før den bliver til Marshall McLuhans "globale landsby", men landsbyerne rundt om i verden er med stor hast ved at blive globaliserede. For mange år siden konkluderede Robert Redfield, der havde udforsket resterne af det førmoderne landlige liv, at "bondekulturen", ufuldstændig og uselvtilstrækkelig som den er, ikke på passende vis kan beskrives, for slet ikke at tale om forstås, med mindre det foregår inde for rammerne af dens omegnsområder, der inkluderer et bydistrikt, hvori byboerne lever i gensidig afhængighed og hjælp. Hundrede år senere kan vi hævde, at den eneste ramme, gennem hvilken alle landlige aspekter skal betragtes for på fyldestgørende vis at kunne beskrives og forklares, er den, der består af kloden. At inkludere en nærliggende by, uanset hvor stor, i billedet er ikke længere tilstrækkeligt. Både landsbyen og storbyen udgør legepladser for kræfter, der befinder sig langt hinsides deres rækkevidde - og for de processer, som disse kræfter sætter i gang men som ingen, hverken de berørte landsbyboere og bymennesker eller initiativtagerne selv, kan forstå for slet ikke at tale om at kunne kontrollere. Det gamle ordsprog om, at mænd skyder, men Gud bærer kuglerne, behøver omskrivning: Landsbyboere og storbymennesker affyrer måske missilerne, men det er nu de globale markeder, der fører dem med sig.

I dens faste rubrik "Countryside Commentary" udgav Corner Post den 24. maj 2002 en artikel af Elbert van Donkersgoed (strategisk politisk rådgiver for The Christian Farmers' Federation of Ontario, Canada) med den sigende titel: "Globaliseringens bivirkninger". "Hvert år producerer vi større mængder fødevarer med anvendelse af mindre menneskelig arbejdskraft og en mere rationel anvendelse af ressourcerne", bemærkede van Donkersgoed. "Landmændene har været dygtigere til deres arbejde, har investeret $i$ arbejdsbesparende 
teknologi og i en finjusteret markedsføring med henblik på kvalitetsproduktion". Der er behov for færre og færre mennesker til at udføre arbejdet. I løbet af fire år op til februar 2002 er 35.000 af dem forsvundet fra statistikkerne over Ontario. De er blevet overflødiggjort af "teknologiske fremskridt" eller er erstattet af ny og forbedret (hvilket vil sige mere arbejdsbesparende) teknologi. Pointen er dog, at ifølge grundbøger iøkonomi og ikke mindst almindelig sund fornuft så burde sådan en spektakulær stigning i produktiviteten have medført et rigere ruralt Ontario og burde have sendt de lokale landmænds profitter i vejret - men der var intet tegn på stigende velstand. Van Donkersgoed fremkommer med den eneste åbenlyse konklusion: "Fordelene fra den landlige produktivitetsforbedring akkumuleres andetsteds i økonomien. Hvorfor? Globalisering". "Globaliseringen", siger han, skabte

et interessefællesskab og et opkøbsmønster bestående af de firmaer, der leverer input til landbrugsproduktionen ... Rationalet om, at "dette er nødvendigt for at være konkurrencedygtig på det internationale marked" er måske sandt, men disse interessefællesskaber har også skabt en monopolistisk ramme, der "tilegner sig alle fordelene ved landmændenes produktivitetsforbedringer". Det følger heraf, at store firmaer bliver udplyndrende giganter, som dernæst erobrer markeder. De kan - og vil - anvende økonomisk magt til at opnå, hvad de ønsker fra landbrugssektoren. Frivillige udvekslinger og handler mellem ligeværdige parter viger til fordel for en befalings- og kontrolorienteret rural økonomi. ${ }^{6}$

Lad os bevæge os et par tusinde kilometer sydøst for Ontario - til Namibia, der statistisk set er et af de mest velstående lande i Afrika. Som Keen Shore rapporterer, er andelen af den landlige befolkning i Namibia, der hidtil har været et udpræget landbrugsland, inden for det seneste tiår faldet drastisk, alt imens befolkningen i hovedstaden Windhoek er fordoblet ${ }^{7}$. Den arbejdsløse overskudsbefolkning fra landdistrikterne er flyttet til de skurbyer, der er vokset frem i udkanten af den relativt velstående storby - tiltrukket af "håbet, ikke realiteterne", eftersom "udbuddet af jobs nu er mindre end antallet af ansøgere". Som Bruce Frayne, en byplanlægger i Namibia og prisbelønnet forsker fra Queens University of Canada, opdagede, "indikerer det blotte antal af mennesker, der flytter ind til storbyen, sammenlignet med ekspansionen i den urbane økonomi i Windhoek, at der findes en forfærdelig masse mennesker, der faktisk ikke har nogen indkomst". Det rurale Namibia vedbliver med at skille sig af med sin overskydende arbejdskraft, alt mens kapitalvæksten i det urbane Namibia ikke er omfattende nok til at absorbere de arbejdsløse. På en eller anden måde er det ekstra overskud, der var i udsigt på baggrund af stigningen i landbrugets produktivitet, hverken havnet i landdistrikterne eller i byerne. Vi kunne, ved at følge van Donkersgoed, stille spørgsmålet "hvorfor?", og som ham svare: "globalisering". 
I de dele af kloden, der må holde for i forhold til globaliseringens hårdtslående påvirkninger, "er byerne omdannet til flygtningelejre for det landlige livs udstødte", bemærker Jeremy Seabrook, der efterfølgende beskriver det byliv, som disse udstødte efter al sandsynlighed vil støde på:

Der er ingen, der tilbyder et job. Mennesker omdanner sig til rickshawkørere eller tjenere, køber en klase bananer og spreder dem ud på fortovet til salg, eller tilbyder sig selv som dragere eller manuelle arbejdere. Dette er den uformelle sektor. I Indien er mindre end 10\% af befolkningen ansat i den formelle økonomi, og denne andel reduceres til stadighed af privatiseringen af statens aktiviteter8.

Som Nan Ellin, der er en af de mest skarpsindige udforskere og indsigtsfulde fortolkere af nutidens urbane udviklinger, bemærker, var beskyttelse mod farer

den primære årsag til at bygge byer, hvis grænser ofte blev defineret af omfattende bymure eller indhegninger, lige fra de ældgamle byer i Mesopotamien til middelalderbyerne op til de indianske stammesamfund 9 .

Murene, voldgravene eller palisaderne markerede grænsedragningen mellem "os" og "dem", orden og vildnis, fred og krig - fjenderne var dem, der befandt sig på den anden side af hegnet, som det ikke var dem tilladt at krydse. "Fra at være et forholdsvis sikkert sted", er byen på den ene eller anden måde, og særligt inden for det seneste århundrede, blevet associeret "mere med fare end med sikkerhed“. I dag, i en mærkværdig omvendelse af deres historiske rolle og stik imod deres oprindelige intentioner og forhåbninger, er vores byer hastigt ved at forvandle sig fra at udgøre et ly mod farer til at være den primære kilde til farer. Diken og Laustsen går så langt som til at hævde, at den årtusind gamle

forbindelse mellem civilisation og barbari er blevet vendt om. Bylivet forandrer sig til en naturtilstand karakteriseret ved et terrorherredømme, der ledsages af en allestedsnærværende fryg $t^{10}$.

Man kan hævde, at kilderne til fare nu er flyttet ind i byens hjerte. Venner, fjender og mest af alt de undvigende og mystiske fremmede, der svinger mellem disse to yderpunkter, blander sig med hinanden og kommer i nærkontakt på byens gader og stræder. Krigen mod usikkerhed, fare og risiko føres nu inde $\mathrm{i}$ byen, og det er herinde, at slagmarkerne markeres og frontlinierne trækkes op. Tungt bevæbnede skyttegrave og bunkere, der er konstrueret med henblik på at adskille, holde de fremmede væk og hindre deres mulighed for adgang, 
er hastigt ved at blive et af de mest synlige træk ved nutidens storbyer - selvom de antager mange forskellige former, og til trods for at deres designere ihærdigt forsøger at få deres skabninger til at smelte ind i det urbane landskab, hvorved de forsøger at "normalisere" den undtagelsestilstand, som de sikkerhedsnarkotiske byboere dagligt oplever.

Den mest udbredte form for forsvarsbefæstning er de stadig mere populære "portfællesskaber" (med betoningen i ejendomsmæglernes brochurer og i beboernes adfærd på "port"- og ikke på "fællesskabs"-delen) med de obligatoriske vagtværn og video-overvågning ved indgangen. Antallet af "portfællesskaber" har i USA allerede oversteget tyvetusinde, mens deres indbyggertal voksede til mere end otte millioner. Betydningen af ordet "port" bliver stadig mere detaljeret med tiden; eksempelvis er et californisk portfællesskab med navnet "Desert Island" omkranset af en femogtyve hektar stor voldgrav, og Brian Murphy byggede et hus til Dennis Hopper i Venice, Californien, med en bunkerlignende metal-facade bestående af bølgeblik og uden nogen vinduer. Den samme arkitekt byggende endnu en luksusvilla i Venice inden for murene af en gammel forfalden ejendom ved først at overmale den med graffiti, for således at få den til at falde i med det vandaliserede nabolag.

Den designede og kunstige konstruktion af det uanselige er en trend, der breder sig i den frygtstyrede urbane arkitektur; en anden er intimidering - enten ved at skabe et afskrækkende ydre, hvis fæstningslignende fremtoning gøres endnu mere frastødende og skræmmende på grund af en overflod af særdeles tydelige kontrolsteder og uniformerede vagter, eller af den uforskammede og demonstrative fremvisning af velhavende, prangende og overpyntet tingeltangel.

Frygtens og intimideringens arkitektur breder sig nu udover byens offentlige områder og forvandler dem på utrætteligt omend uigennemskuelig vis til tæt bevogtede og konstant overvågede steder. Opfindsomheden kender på dette punkt ingen grænser. Nan Ellin omtaler et par i overvejende grad oprindeligt amerikanske men nu også vidt og bredt imiterede anordninger såsom "tiggersikre" tøndeformede bænke kombineret med sprinklersystemer i parkerne i Los Angeles (mens København gik et skridt endnu videre ved at fjerne alle offentlige bænke fra Hovedbanegården og ved at uddele bøder til de ventende passagerer, der hvilede sig på gulvet), eller sprinklersystemer kombineret med den øredøvende larm af mekanisk musik for at skræmme hjemløse og tiggere væk fra områderne omkring forretningerne.

Hvad angår virksomhedernes hovedkontorer og stormagasiner, der indtil for ikke så længe siden udgjorde leverandører, brændpunkter og magneter for det urbane rum, er de nu i stedet interesserede $i$ at flytte ud fra bycentrene ind i kunstige, splinternye konstruerede miljøer med et vist bylivsimiterende tilbehør såsom forretninger, restauranter og visse spredte beboelsesområder, der er inkluderet for at camouflere den gennemgribende måde, hvorpå byens primære tiltrækningskraft - dens spontanitet, fleksibilitet og evne til at overraske 
og tilbyde eventyrlige oplevelser (alle årsagerne til at Stadtluft blev anset som frei machen) - er blevet skåret væk og uddrevet. Som et eksempel på denne symbolsk ladede tilbøjelighed kan man betragte Københavns havnefront bestående af imponerende men dog ikke desto mindre uimødekommende, tungt befæstede og omhyggeligt indhegnede kontorbygninger, som det er meningen, at man skal beundre på afstand på samme måde som de usynlige mure ved La Défense i Paris, men som det ikke er meningen, at man skal aflægge besøg. Budskabet er klart og umiskendeligt - de, der arbejder for virksomhederne inden i bygningerne, beboer det globale cyberspace, og deres fysiske forbindelse til byens rum er overfladisk, kontingent og løsrevet - og den monolitiske facades ophøjede og selvindbildske grandiositet, der blot gemmer på nogle få nøje camouflerede indgange, tilkendegiver netop dette. Insiderne befinder sig $i$ men er ikke af det sted, hvori deres kontorbygninger er blevet rejst. Deres interesser retter sig ikke længere mod den by, hvor de for en stund tilfældigvis vælger at slå lejr; den eneste service, som de forlanger af byens beboere, er, at de bliver ladt i fred. Eftersom de kun beder om lidt, føler de sig ej heller forpligtede til at tilbyde meget til gengæld.

Richard Rogers, en af de mest berømmede og anerkendte engelske arkitekter, advarede på følgende måde deltagerne i et byplanlægningssymposium, der blev afholdt i Berlin i 1990:

Hvis vi foreslår et projekt til en investor, så spørger han øjeblikkeligt: "Hvorfor er der brug for træer, hvorfor arkader?". Investorer er kun interesserede i kontorfaciliteter. Såfremt du ikke kan garantere for, at bygningen inden for højst ti år vil kunne betales ud, så er der ingen grund til overhovedet at kontakte dem ${ }^{11}$.

Rogers beskriver London, hvor han har lært denne bitre lektie, som en "politisk paralyseret by, der næsten udelukkende forekommer at være i lommerne på byplanlæggerne“. Når det drejer sig om de virkeligt grundlæggende byfornyelser, som den i europæisk sammenhæng mest gennemgribende genskabelse af dokområderne i London, blev byggeplanerne godkendt på baggrund af mindre granskninger, end det havde været tilfældet for "en ansøgning om byggetilladelse til et lysskilt på en fish and chips-forretning på East India Dock Road". Det offentlige rum var det første offer for bivirkningerne af den kendsgerning, at byen tabte den tunge kamp i forhold til at dæmme op for eller i det mindste tage farten af den ubarmhjertige fremrykning af globaliseringens uimodståelige kraft. Og derfor, konkluderer Rogers, er "det, vi virkelig har brug for, en institution, der vil beskytte det offentlige rum".

Dette er tydeligvis lettere sagt end gjort... Hvor kan vi finde en sådan institution? Og hvis vi fandt den, hvordan kunne den vise sig på højde med situationens alvor? 
Byplanlægningens historie er indtil videre - nu måske mere end førhen - langt fra opmuntrende læsning. Om konsekvensen af Londons byplanlægning havde dens skarpsindige kronikør John Reader eksempelvis følgende at berette:

\begin{abstract}
Den samfundsmæssige orden i og sociale sammensætning af Londons befolkning var under forandring, men på en måde, der langt fra var relateret til det, byplanlæggerne havde forestillet sig eller troet udgjorde idealet. Dette var et klassisk eksempel på, hvordan ændringer i økonomi, samfund og kultur kan stride imod - sågar afkræfte - de tanker og teorier, som planlæggere har fremført $\mathrm{t}^{12}$.
\end{abstract}

I løbet af de første tre efterkrigsårtier kom Stockholm - en by, som anerkendte og helhjertet tillagde sig de store modernistiske og modernistisk-inspirerede visionæres opfattelse af, at man ved at omskabe det rum, som mennesker beboede, også kunne forbedre samfundets indretning og væsen - måske mere end nogen anden storby tættere på at implementere det "socialdemokratiske utopia“. De lokale myndigheder i Stockholm tilvejebragte ikke blot alle dens indbyggere en tilfredsstillende bolig men også med en lang liste over levevilkårsfremmende faciliteter og en fuldt ud sikret tilværelse. Men i løbet af blot tre årtier er den folkelige stemning, til byplanlæggernes store overraskelse, begyndt at forandres. Den planlagte ordens velsignelser blev på ironisk vis draget $i$ tvivl netop af de (unge) mennesker, som voksede op i det omorganiserede byrum, der som udgangspunkt havde forbedringer af beboernes liv for øje. Indbyggerne, og særligt de yngre indbyggere i Stockholm, bakkede ud af det totalt forudsigelige, gennemplanlagte og altfavnende kommunale boligsystem og kastede sig hovedkulds ud i det private ejendomsmarkeds turbulente bølger. Konsekvenserne af deres massive rømning var, som Peter Hall konstaterede, i det store og hele ufordelagtige "med tætpakkede huse i fantasiløst ensartede rækker, der bragte mindelser om den værste type af amerikanske forstadskvarterer" - "men efterspørgslen var voldsom og husene blev hurtigt solgt" ${ }^{\prime \prime}$.

Usikkerhed avler frygt, og det er ikke uden grund, at kampen mod usikkerhed står højt på byplanlæggernes prioriteringsliste; eller i det mindste føler de, og insisterer såfremt adspurgt herom på, at det burde den. Problemet er dog, at sammen med usikkerhed er alle byens fremmeste tillokkelser som spontanitet, fleksibilitet, overraskelses- og oplevelsesmomenterne dømt til at forsvinde fra byens gader og stræder. Alternativet til usikkerhed er ikke en lyksalig fred og ro, men derimod en kedsomhedens forbandelse. Er det overhovedet muligt at overvinde frygten, samtidig med at man undslipper kedsomheden? Man må antage, at en besvarelse af dette spørgsmål udgør den største gåde for byplanlæggere og arkitekter - en gåde, hvorpå der endnu ikke er fundet en overbevisende, tilfredsstillende eller uomtvistelig løsning; et spørgsmål, hvortil et fuldt ud tilfredsstillende svar måske aldrig vil kunne findes, men et spørgsmål 
som (måske af selvsamme årsag) vil vedblive med at anspore arkitekterne og planlæggerne til endnu mere ekstrem eksperimentering og til stadig mere vovede opfindelser.

Lige fra begyndelsen har byerne været steder, hvor fremmede levede sammen i umiddelbar nærhed af hinanden, alt imens de forblev fremmede for hinanden. At være i selskab med fremmede er altid skæmmende (omend ikke altid frygtet), eftersom det hører til de fremmedes væsen, i modsætning til både venner og fjender, at deres hensigter og deres måder at tænke og reagere på fælles oplevelser på forekommer ubekendte og heller ikke bringer vished nok til at kunne forudberegne sandsynligheden for deres adfærd. Forsamlingen af fremmede udgør en kilde til endemisk og uhelbredelig uforudsigelighed. Man kan også sige det på en anden måde: De fremmede legemliggør risiko. Der findes ingen risiko uden i det mindste en rest af frygt for at blive gjort fortræd eller for at lide nederlag, men uden risiko er der heller ingen chance for gevinst eller triumf. Derfor kan områder, der gennemsyres af risiko, kun opfattes som steder for endemisk tvetydighed, som til gengæld blot afføder ambivalente holdninger og handlinger. Områder gennemsyret af risiko er tilbøjelige til på en og samme tid både at tiltrække og frastøde, og det særlige punkt, hvor den ene reaktion forvandles til sin modsætning, er særdeles varieret, foranderligt og næsten umuligt at kunne lokalisere for slet ikke at tale om at kunne fikseres.

Rummet er "offentligt" i den forstand, at de mennesker, der tillades adgang, og som sandsynligvis vil ansøge om adgang, ikke er udpegede på forhånd. Der findes intet adgangskort og ingen registrering af dem, der kommer og går. Tilstedeværelsen i det offentlige rum er derfor anonym, og således er de, der er tilstede i det offentlige rum, uundgåeligt fremmede for hinanden såvel som for de mennesker, der opretholder kontrollen over det offentlige rum. Det offentlige rum består af steder, hvor fremmede mødes, og dermed er det en kondensering og sammenfatning af bylivets karakteristiske træk. Det er i det offentlige rum, at bylivet og alt det, der gør det muligt at skelne det fra andre former for menneskeligt samvær, når sin mest fuldendte udtryksform med dens mest karakteristiske sorger og glæder, forudanelser og forhåbninger.

Offentlige steder er af disse grunde lokaliteter, hvor tiltrækning og frastødning kappes med hinanden i ustabile, konstant og hastigt foranderlige målestoksforhold. Derfor er de sårbare steder, der udsættes for maniodepressive eller skizofrene anfald - men også steder, hvor tiltrækningen har en chance for at opveje eller neutralisere frastødningen. De er, med andre ord, steder, hvor omstændighederne for et betryggende byliv opdages, tillæres og først praktiseres. Offentlige rum udgør de pletter på landkortet, hvor fremtiden for det urbane liv (og givet det faktum at et voksende flertal af jordens befolkning udgøres af byboere således også fremtiden for samværet mellem mennesker på vores klode) netop på nuværende tidspunkt bliver afgjort. 
Lad os skære helt ind til benet: Der er ikke blot tale om enhver form for offentligt rum, men kun de blandt dem, der på den ene side enten opgiver de modernistiske ambitioner om at tilintetgøre og udjævne forskelligheder eller som på den anden side opgiver den postmoderne tendens til at fastfryse forskelligheder gennem gensidig adskillelse og fremmedgørelse. Der er tale om offentlige steder, der anerkender den kreative og livsbekræftende betydning af mangfoldighed, samtidig med at de muliggør en meningsfuld dialog mellem forskelligheder. For atter at citere Nan Ellin, gør det offentlige rum, "ved at tillade en mangfoldighed (af mennesker, aktiviteter, holdninger etc.) at blomstre", det muligt at integrere (eller genintegrere) "uden at udslette forskelligheder; faktisk fejrer det forskellighederne. Følelser af frygt og usikkerhed lindres gennem bevarelsen af forskelle sammen med muligheden for at bevæge sig frit gennem byen“. Det er tilbøjeligheden til at trække sig tilbage fra det offentlige rum og ind i små isolerede enklaver af ensartethed, der med tiden kommer til at udgøre den største forhindring for at kunne leve med forskellighed, fordi den bevirker, at de dialogiske og forhandlingsmæssige færdigheder falmer og visner. Det er derimod udsættelsen for forskellighed, der med tiden kan vise sig at udgøre den primære baggrund for et lykkeligt samvær, fordi den bevirker, at den urbane frygts rødder vil falme og visne.

Sådan som tingene med deres egen indre dynamik for nuværende udvikler sig, kan vi fornemme en voksende fare for, at den offentlige sfære, som Jonathan Manning fra South-African Ikemeleng Architects livagtigt beskrev det, reduceres

til det uanvendelige rum, der er blevet tilovers mellem enklaver af private rum. Menneskelig samhandling er i dette sterile tiloversblevne rum begrænset til konflikter mellem bilister og fodgængere, de velstillede og de underprivilegerede, hvadenten det drejer sig om at sælge varer ved lyskryds, kollisioner mellem køretøjer og fumlegængere, butiksrøverier og biltyverier. Kontaktfladerne mellem den offentlige sfære og det private rum ... udgøres enten af butiksfacader, med det formål at sælge varer, eller af detaljerede mekanismer til at holde mennesker væk så som vagtbygninger, mure, pigtråd eller elektriske hegn.

Manning afslutter sin analyse med at appellere til

et skift i fokus fra at designe private rum til at designe mere omfattende offentlige rum, der både er brugbare og stimulerende ... Det skal kunne varetage en mangfoldighed af forskellige funktioner og fungere som en katalysator snarere end som en forhindring for menneskelig samhandling. ${ }^{14}$ 
Hvad angår Nan Ellin, så opsummerer hun sin undersøgelse med at argumentere for en "Integrerende Urbanisme", som henviser til en tilgang, der betoner "sammenhæng, kommunikation og festligholdelse". Og hun tilføjer:

Vi er nu konfronteret med en udfordring, der består af at skabe byer på en måde, der værner om de fællesskaber og omgivelser, der i sidste instans opretholder os. Det er en svær udfordring, men den er ikke desto mindre af afgørende betydning.

Der kan ikke herske tvivl om indsigten i og nødvendigheden af disse appeller. Dét, der er behov for, er, at vi kan leve op til denne utvivlsomt "svære" men dog afgørende udfordring. Således er det en af de sværeste opgaver, som vores hastigt globaliserende klode står overfor, men også en, som vi må konfrontere på en direkte og yderst presserende måde - og ikke bare for byboernes velbefindendes skyld. Som Lewis H. Morgan opdagede for efterhånden længe siden, så "tilbyder arkitekturen en fyldestgørende illustration af fremskridtet fra barbari til civilisation“15.

Tillad mig at tilføje, at "civilisationens fremskridt" ikke blot er en engangsforeteelse men en vedvarende og daglig kamp; en kamp, som aldrig fuldt ud er sejrrig, og som synes utilbøjelig til nogensinde at nå til mållinien, men også en kamp, som altid tilføres mod i forhåbningen om sejr.

Oversat fra engelsk af Michael Hviid Jacobsen

\section{Noter}

1. The Hedgehog Review, efterår 2003, 5 (3):5-7.

2. David L. Altheide (2003): "Mass Media, Crime and the Discourse of Fear". The Hedgehog Review, 5 (3):9-25.

3. Stephen Graham (2004): "Postmortem City: Towards an Urban Geopolitics". City, 2:165-196.

4. Ray Surette (1992): Media, Crime and Criminal Justice. Pacific Hgrove, CA: Brooks Cole, s. 43.

5. Se John Vidals rapport “Beyond the City Limits“ i online-tillægget til The Guardian, 9. september 2004, s. 4-6.

6. Forefindes i arkivet på www.christianfarmers.org.

7. Se http:/wweb.idrc.ca/en/ev-5376-201-1-DO_TOPIC.html.

8. Jeremy Seabrook (2004): Consuming Cultures: Globalization and Local Lives. Oxford:New Internationalist Publications. Her citeret fra et udkast med titlen "Power Keg in the Slum" i The Guardian, 1. september 2004, s. 19.

9. Nan Ellin (2003): “Fear and City Building“. The Hedgehog Review, 5 (3):43-61.

10. Bülent Diken \& Carsten Bagge Laustsen (2002): "Security, Terror and Bare Life". Spaceand Culture, 2:290-307.

11. Her citeret efter John Reader (2004): Cities. London: Heinemann, s. 282.

12. Ibid., s. 267. 
13. Peter Hall (1998): Cities in Civilization: Culture, Innovation and Urban Order. London: Weidenfeld \& Nicolson, s. 875-876.

14. Jonathan Manning (2004): "Racism in Three Dimensions: South African Architecture and the Ideology of White Superiority“. Social Identities, 4:527-536.

15. Lewis H. Morgan (1878): Ancient Society. New York: Henry Holt, s. 1. 